Manca Kladnik

OŠ Jakoba Aljaža, Kranj

manca.kl@gmail.com

Mateja Dagarin Fojkar

Pedagoška fakulteta, Univerza v Ljubljani

Mateja.Dagarin@guest.arnes.si
UDK 811.111'243:373.3

DOI: $10.4312 /$ vestnik.6.177-193

\title{
POUČEVANJE ANGLEŠČINE NA ZGODNJI STOPNJI PO METODI HELEN DORON
}

\section{UVOD}

Živimo v času, ko se naša vsakodnevna komunikacija odvija v večkulturnem in večjezičnem svetu. Ohranjanje in spodbujanje večjezičnosti je tudi eno izmed temeljnih načel Evropske unije. Zaželena formula znanja jezikov se glasi $1+2$, po kateri naj bi vsak Evropejec obvladal svoj materni jezik in dva tuja (Pižorn 2009). Tudi v Sloveniji stremimo k tej formuli. V letošnjem šolskem letu (tj. 2014/2015) se je pričelo postopno uvajanje prvega tujega jezika v 2. razred osnovne šole. Poleg formalnega učenja angleščine v šoli pa v Sloveniji obstaja več jezikovnih centrov za poučevanje angleščine, med katerimi so tudi jezikovni centri Helen Doron Early English. V njih poteka poučevanje angleščine na (zelo) zgodnji stopnji po metodi Helen Doron Early English (v nadaljevanju HDEE).

Metoda HDEE je v Slovenijo prišla leta 2011, ko se je odprl njihov prvi jezikovni center v Ljubljani (www.helendoron.si). Glavna posebnost te metode (v primerjavi z ostalimi) je, kot pravi nosilka metode Helen Doron (www.helendoron.com), da so bili prvi, ki so začeli poučevati angleščino za otroke in dojenčke kot materni jezik na sistematičen način (ang. systematic mother-tongue methodology). Popularnost metode se kaže v njeni razširjenosti; več kot 750 jezikovnih centrov Helen Doron je v več kot 30 državah po vsem svetu, obe številki pa se iz leta v leto povečujeta (Doron 2010). V Sloveniji se je od leta 2011 odprlo že sedem jezikovnih centrov (www.helendoron.si).

Zanimivo je, da so vsi viri o tej metodi in o metodah na katerih sloni, večinoma dostopni le na spletu. Edina knjiga, iz katere sva lahko črpali informacije, je The Music of Language (2010), ki jo je napisala nosilka metode Helen Doron.

Kljub trditvam Doronove, da je metoda drugačna od ostalih metod za zgodnje poučevanje tujih/drugih jezikov (TJ/J2), pa izhaja iz povsem temeljnih načel za zgodnje poučevanje TJ/J2, ki se uspešno uporabljajo tudi v šolah in ostalih jezikovnih centrih. Metoda 
tako potrjuje temeljna načela o zgodnjem poučevanju, ki so v strokovnih krogih že znana, empirična raziskava v drugem delu članka pa jih prikaže tudi s praktičnega vidika.

\section{VPLIVI NA METODOLOGIJO}

Helen Doron se je že v družinskem okolju naučila veliko, kar ji je kasneje pomagalo pri razvoju metodologije. Dedek je bil dober poslovnež, mati učiteljica angleščine, od očeta pa je prevzela predvsem empatijo do vsega živega (Doron 2010).

Odraščala je v Londonu, kjer je obiskovala Montessori vrtec, nato pa so jo starši vpisali v zasebno šolo z zelo progresivnim programom. Učenje je potekalo v majhnih skupinah, učno okolje je bilo prijazno in spodbudno, otroci pa so lahko napredovali po lastnem tempu. Na tej šoli se je Helen pri sedmih letih začela učiti francoščino in latinščino. Pri petih letih se je začela učiti tudi klavir. Pri enajstih letih se je morala zaradi slabšega finančnega stanja družine prepisati na Henrietta Barnett Grammar School. Tam ji način poučevanja ni ustrezal, tako je videla, kakšen vpliv na otroka ima lahko sistem poučevanja (prav tam).

Študij je nadaljevala na Reading University, kjer se je vpisala na program francoščine in angleške literature. Kasneje jo je navdušil tudi predmet jezikoslovje in na koncu je diplomirala iz jezikoslovja in francoščine. Del študija jezikoslovja je bil tudi predmet usvajanje jezika pri otrocih, ki je postal osnova za kasnejši razvoj metodologije za HDEE.

Doron v svoji knjigi opisuje tudi druge, manjše vplive na njeni življenjski poti, ki so pripomogli k razvoju metodologije. Eden od teh je vegetarijanstvo in transcendentalna meditacija. V tej metodi in načinu življenja je Helen našla svoj notranji mir. Tudi njeno šibko zdravje v mladostniških letih je posredno vplivalo na razvoj metode. Pravi, da se je pozdravila s pomočjo homeopatije. Tako v njenem zasebnem življenju, kot tudi $\mathrm{v}$ metodah HDEE lahko opazimo naklonjenost alternativam. V HDEE npr. opazimo naklonjenost živalim, saj v didaktičnih materialih ni angleških izrazov povezanih z mesom kot hrano. Prav tako pa, kot homeopatija in transcendentalna medicina, tudi HDEE gleda na celega človeka, torej uporablja holistični pristop (prav tam).

Celostni pristop je temeljni pristop zgodnjega poučevanja TJ/J2, ki upošteva celostni razvoj otroka in ki ga poudarjajo mnogi strokovnjaki (med drugim tudi Brewster, Ellis in Girard 2002, Brumen 2003, Čok 1999, Pevec Semec 2013 in drugi).

\subsection{Vpliv metode Glenna Domana}

Glenn Doman je fizioterapevt in kot pravi sam, pionir razvoja otroških možganov. Leta 1955 je ustanovil The Institutes for the Achievement of Human Potential (Inštitut za dosežke človeškega potenciala - v nadaljevanju IAHP). Inštitut je mednarodno znan po tem, da je eden prvih, ki so se posvečali razvoju otroških možganov. V njem so 
razvili programe, ki pomagajo otrokom s poškodbami možganov. Od leta 1960 je inštitut IAHP začel ponujati programe, namenjene pospeševanju razvoja možganov pri zdravih otrocih. Doman vidi otrokov potencial v tem, da se možgani razvijajo z uporabo. Hitreje kot kadarkoli v življenju se razvijajo v prvih šestih letih. Poudarja tudi, da otroka lahko naučimo česarkoli, če mu to predstavimo na iskren, stvaren in radosten način. Mati in oče sta po njegovem mnenju najboljša učitelja, kar jih otrok lahko ima. Pravi, da bi se morali otroci branja učiti doma, ne v šoli. Učenje je namreč otrokova pravica, ki jim je dana z rojstvom. Zelo majhni otroci, celo dojenčki, so že pripravljeni za branje, ker je branje naravno in zabavno (The Institutes for the Achievement of Human Potential).

Metoda Glenna Domana je tako inovativna kot tudi provokativna. Starost, ko naj bi dojenčka začeli učiti brati, je po njegovem namreč 10 mesecev. Glavna metoda za učenje branja je uporaba slikovnih kartic (ang. flashcards) (prav tam).

Na spletu lahko preberemo veliko kritik in tudi veliko navdušenja glede Domanove metode. Strokovni članki pogosto kritizirajo Domanove metode zaradi premalo strokovnega ozadja ter oglaševanja dobrih rezultatov brez dokazov (Committee on Children with Disabilities 1999). To velja tako za otroke z okvarami na možganih kot za otroke, ki jim želijo »pospešiti kognitivni razvoj«. Kritiki poudarijo tudi, da starši v teh programih življenje celotne družine posvetijo le programu ter s tem zanemarijo ostale člane družine. Polega tega pa imajo starši previsoka pričakovanja in so zato preveč razočarani ob otrokovem neuspehu (prav tam).

Nekatera izmed Domanovih načel se delno ujemajo s hipotezo o kritičnem obdobju učenje jezika (ang. The Critical Period Hypothesis), ki trdi, da se otroci do pubertete učijo jezik lažje in hitreje kot odrasli, ker se predel za učenje jezika v človeških možganih do pubertete še oblikuje, potem pa zakrkne. Dokazi, ki govorijo v prid hipotezi o kritičnem obdobju, so nastali na podlagi opazovanj ljudi z možganskimi poškodbami, ki jih je raziskoval nevrofiziolog Penfield (1959), in redkih primerov otrok, ki niso bili deležni običajne vzgoje in učenja jezika. Lenneberg (1967) je hipotezo razširil tudi na učenje TJ/J2. Svojo tezo je podprl s trditvijo, da se to obdobje ujema z lateralizacijo, to je s postopnim premikom jezika na eno stran možganov, navadno levo. Predvideval je, da je po tem obdobju učenje novega jezika veliko težje in tako poimenoval to dobo biološko kritično za učenje jezika. Kasnejše študije so pokazale, da se Lenneberg delno moti lateralizacija se pojavi zelo zgodaj v življenju, mogoče celo ob rojstvu in še ne pomeni izgube kakršnihkoli sposobnosti (Krashen 1975 v Stern 1983: 362).

\subsection{Vpliv metode Suzuki}

Največji vpliv na razvoj in začetek metodologije HDEE je metoda dr. Shinichi Suzukija, imenovana metoda Suzuki (ang. the Suzuki Method). Ko je bila njena hčerka Ella stara štiri leta, jo je Helen želela vpisati na ure učenja glasbe. Našla je učenje violine po 
metodi Suzuki. Ko je prisostvovala pri prvi uri in bila priča filozofiji ter metodologiji ustanovitelja metode, dr. Shinichija Suzukija, je bila popolnoma navdušena in takoj prebrala vse knjige o njem ter njegovi metodologiji (Doron 2010).

Še preden je Suzuki začel s svojim delom z otroki, ga je fasciniralo dejstvo, da vsi otroci že pri petih ali šestih letih tako dobro obvladajo materinščino (v tem primeru japonščino), celo nekatere težke dialekte, kako dobro razlikujejo odtenke in obvladajo izgovarjavo nekaterih težkih besed. Tako je razvil »metodo materinščine« (ang. Mother Tongue Method) (Suzuki 1981). Metoda materinščine je torej najboljša, podzavestna metoda za učenje jezika. Suzuki pa je dalje raziskoval in ugotovil, da bi to metodo lahko uporabili tudi na drugih izobraževalnih področjih. Sklenil je, da bi se otroci na tak način lahko naučili tudi glasbe, če bi se poučevala z ljubeznijo in predanostjo. Njegov cilj je bil zajeti celotnega otroka, mu gojiti ljubezen do glasbe in razvoj dobrega karakterja in ne samo učenje glasbenega inštrumenta (http://www.suzukimusic.org.au/ suzuki.htm\#history).

Z idejo, da sta učenje TJ/J2 in usvajanje MJ podobna procesa se je ukvarjalo že veliko jezikoslovcev, med drugimi tudi Stern (1983 v Skela in Dagarin Fojkar 2009) s svojo hipotezo identičnosti (ang. identity hypothesis), ki temelji na predpostavki, da sta usvajanje $\mathrm{MJ}$ in $\mathrm{TJ} / \mathrm{J} 2$ istovetna procesa, ki ju usmerjajo iste zakonitosti in mehanizmi. Podobno sta Krashen in Terrell (1983) razvila hipotezo o razliki med učenjem in usvajanjem jezika (ang. learning - acquisition hypothesis), s katero sta trdila, da se usvajanje jezika odvija na podzavestni ravni in je podobno otrokovemu usvajanju MJ, iz česar sta povzela, da če želimo tuji jezik tekoče govoriti, samo zavestno učenje ni dovolj, ampak ga moramo tudi usvojiti. Iz teh hipotez se je razvilo kar precej naravnih metod učenja jezikov, katerih glavna predpostavka je bila, da bi moralo učenje TJ potekati na podoben način kot usvajanje materinščine. Kljub nekaterim podobnostim med tema dvema procesoma pa so učni pogoji še vedno zelo različni, npr. učno okolje, motivacija ter izpostavljenost jeziku.

\section{KRITIKA TRADICIONALNEGA UČENJA TUJEGA JEZIKA}

Doron (2010) zelo kritizira javni šolski sistem in pravi, da kljub temu, da se mnoge države zavedajo pomembnosti angleščine, se že v šolskem kurikulumu pojavi osnovna napaka. Od učencev se pričakuje, da sočasno obvladajo vse vidike jezika (branje, pisanje, govor, razumevanje, slovnico in glasoslovje). Otrok, ki je star 10 let, mora $v$ šoli naenkrat sprejemati vse te informacije, vključno z abstraktnimi slovničnimi pravili, ki jih težko razume.

Učenci nimajo dovolj časa za individualni govor v tujem jeziku. V številčnih razredih večinoma lahko delajo le $\mathrm{v}$ skupinah in nimajo dovolj časa za individualni govor. Izpostavi še problem, da običajno »boljšiß učenci večkrat pridejo do besede, bolj plahi pa ostanejo tiho in tako nimajo možnosti se preizkusiti v konverzaciji. 
Prav tako po njenem mnenju učenci ne dobijo dovolj neposredne povratne informacije. Doron (prav tam) zopet izpostavi problem števila učencev na enega učitelja, ki naj ne bi mogel dati dovolj povratnih informacij. Opozori nas, naj to primerjamo z vsemi odzivi, ki jih dojenček dobi od staršev pri učenju maternega jezika. Zapiše celo, da se v tako velikih razredih učenec lahko več let uči jezika, ne da bi kdajkoli dosegel minimalni nivo aktivnega znanja.

Razlog za naslednji neuspeh je slaba izgovarjava učiteljev. Problem, kot pravi Doron (prav tam), je v pomanjkanju učiteljev, ki so domači govorci.

Tradicionalni model poučevanja se osredotoča na popravljanje napak. Doron pravi, da je v zahodnih državah povratna informacija največkrat popravljanje napak, naj bo to pri konverzaciji, domači nalogi ali testih (prav tam). Helen Doron utemeljuje, da je svojo metodologijo razvila kot odziv na zgoraj zapisane kritike tradicionalnega sistema (prav tam).

Doronova je v svoji kritiki zajela slabosti britanskega javnega šolstva in jih posplošila na ves svet. Šolski sistemi po svetu so si zelo različni, prav tako so se pristopi k zgodnjemu poučevanju tujih jezikov v zadnjih letih korenito spremenili. Na začetku procesa učenja je le-to osredotočeno na razvijanje poslušanja in govora v TJ, šele kasneje se poučuje tudi branje in pisanje. $Z$ dejavnostmi, prilagojenimi mlajšim učencem, imajo sedaj učenci več možnosti za rabo jezika v razredu, tudi učitelji TJ, ki niso domači govorci, imajo dobro izgovorjavo, saj so večinoma vsakodnevno izpostavljeni angleščini, prav tako se učenje že nekaj časa ne osredotoča več na popravljanje napak.

\section{METODOLOGIJA HDEE}

»Če se lahko glasba poučuje na način maternega jezika, zakaj potem nimamo tudi poučevanja tujega jezika na način učenja maternega jezika?« (Doron 2010: 27). Iz tega je izpeljala: »Če Suzuki uči »jezik glasbe« (ang. the language of music), zakaj nimamo učenja »glasbe jezika« (ang. the music of language), «(prav tam). Ta ideja se ji je zdela še posebej vznemirljiva, posebno tudi z vidika, da je to tudi snov predmeta, ki ji je bil med študijem zelo blizu, tj. jezikovni razvoj otroka.

Začetna točka je bila torej Suzukijeva metoda, vrnila pa se je tudi k metodi Glenna Domana (glej poglavje 2.1.). Helen Doron poudarja, da so mnoge raziskave pokazale, da človekova intelektualna zmožnost ni odvisna le od genetike, ampak tudi od zelo zgodnje stimulacije možganov, ki vodi v razvoj novih nevralnih poti. Ko se te poti razširjajo, nastane prostor za shranjevanje novih informacij. Poudarja, da človeški možgani v starosti do enega leta rastejo najbolj intenzivno. To so osnove za kasnejše miselne zmožnosti, ki bodo določale mnogo stvari, npr. uspeh v šoli, kako bodo kot odrasli sprejemali svojo službo ipd. Kot trden dokaz za nujnost zgodnjega jezikovnega razvoja poda primer volčjih otrok (prav tam), ki je služil tudi kot osnova Penfieldove hipoteze o kritičnem obdobju učenja jezika (glej tudi 2.1.). 
Helen Doron svojo metodologijo povezuje oz. pojasnjuje predvsem z zgodnjim stimuliranjem in s tem razvijanjem možganov s pomočjo zgodnjega usvajanja jezika, kar bo otrokom omogočilo boljši razvoj možganov in boljše možnosti za življenje. V najpomembnejšem, zgodnjem obdobju malček že pasivno sprejema zvoke okolja. In že takrat možgani aktivno analizirajo jezik in ga pripravljajo na prihodnji razvoj. Ustvarijo se povezave med glasom in pomenom, konkretnim samostalnikom ali konceptom. V naravnem okolju imerzije, tj. popolne jezikovne kopeli, od otroka ne pričakujejo učenja slovnice, jezikovnih struktur, učenja branja in pisanja kot v formalnem šolanju. Helen Doron pravi, da je popolna imerzija edini način, da se otroci tako dobro naučijo angleščine, kot bi bila njihov materni jezik. To pa tudi sicer na področju poučevanja tujih jezikov ni novost. Izrazi in sintagme imerzija, jezikovna kopel, tudi jezikovna potopitev (immerse, Immersion, Sprachbad) poimenujejo eno izmed uspešnih, strokovno najbolj podkovanih in empirično raziskovanih metod učenja tujega jezika. V slovenskem jezikovnem prostoru se je vzporedno z imerzijo pojavil tudi izraz jezikovna kopel. Tudi Brumnova (2000) izpostavi to metodo, kot učinkovito metodo »naravnega « zgodnjega pridobivanja tujih jezikov. Jezikovna kopel se nanaša na obliko dvojezičnega poučevanja oziroma učenja tujih jezikov in je lahko popolna ali delna (Jazbec, 2008).

Pomemben podatek je, da otroci zvočne podatke vpijajo, kot goba vpija vodo. Vendar Doron (prav tam) poudari, da je učenje jezika veliko bolj kompleksno od samega sprejemanja zvočnih podatkov. Nadaljuje s tem, da so najmlajši otroci ali dojenčki navadno izpostavljeni pretirani artikulaciji, intonaciji in obrazni mimiki. Odrasli pri pogovorih z otroki velikokrat padejo v otroški govor (ang. baby talk), ki je poln čustev, upočasnjen in $\mathrm{s}$ pretirano obrazno mimiko. To otroke stimulira in pritegne njihovo pozornost. Zato je zatem odrasli nagrajen $z$ veseljem otroka in velikim nasmehom. Vsa ta stimulacija igra veliko vlogo pri tem, da otrok že zgodaj začne ustvarjati povezave. Otroci, ki so prikrajšani za vizualne stimulacije, pravi Doron (prav tam), lahko kasneje doživijo razvojne motnje.

V svoji knjigi Doron (2010: 47) opisuje, da se dojenčki šest ravni maternega jezika (tj. prozodija, glasoslovje, fonologija, morfologija, sintaksa, semantika) naučijo sočasno v starosti do enega leta. Doron (prav tam) piše, da je bilo v zadnjem času več raziskav o tehnikah, ki jih dojenčki uporabljajo za analizo maternega jezika (ali več maternih jezikov, če so dojenčki večjezični). Ta koncept tvori eno od osnov metodologije HDEE. Metodologija sloni na štirih temeljnih principih (prav tam: 49):

- Domače poslušanje posnetkov $\mathbf{v}$ angleščini: posnemanje usvajanja maternega jezika z ustvarjanjem imerzije. Ker se posnetki vrtijo le kot zvočna kulisa, je otrokova pozornost na posnetek nezavedna. In ker je otrok v stiku z jezikom nezavedno, se ta vgradi v dolgotrajen spomin in ustvarja mrežo usvajanja jezika.

- Pozitivna spodbuda (ang. positive reinforcement): spodbujati in podpirati ves otrokov trud. Otroci se maternega jezika naučijo tudi zato, ker so starši navdušeni vsakič, ko nekaj povedo. 
- Učenje je zabava: ustvariti prijazno in spodbudno okolje. Učenje s pomočjo pesmi in iger je ključna sestavina.

- Graditi na uspehu: ustvariti dovolj postopnih izzivov, da otroci ostanejo motivirani in gradijo na uspehu. Prav otrokov uspeh ustvarja motivacijo za učenje. Otrok pa ve, da je uspešen, kadar prejme pozitivno spodbudo.

Principi metodologije HDEE se ujemajo s principi zgodnjega poučevanja TJ/J2, o katerih obširneje pišejo Brewster idr. 2002, Brumen 2003, Cameron 2001, Murphy 2014, Pinter 2006 in drugi.

Vključenost staršev je pomemben element metodologije HDEE. Doron (2010) v svoji knjigi opisuje, da so nekateri starši že avtomatično vključeni v otrokovo izobraževanje. Pregledujejo jim naloge in jim pomagajo, kadar potrebujejo pomoč. Nekateri starši pa imajo pristop »roke stran« (ang. hands off) in izobraževanje otrok prepuščajo institucijam. Tem je treba dopovedati, da je domače poslušanje posnetkov zelo pomemben del programa HDEE in da otrok brez tega ne bo tako užival med urami ter napredoval, kot bi moral. In pri domačem poslušanju so starši tisti, ki nosijo odgovornost za njegovo izvajanje. Poleg tega so v programu tudi določeni materiali, ki staršem omogočajo sodelovati pri otrokovem učenju. Ti pa, nasprotno kot pasivno poslušanje posnetkov, staršem omogočajo aktivno sodelovanje. Vendar lahko starši, kot je Doron (prav tam) že večkrat omenila, s prepogostim popravljanjem ali kritiziranjem otroka naredijo več škode kot koristi. Zato morajo biti starši pravilno podučeni in usposobljeni, da lahko ponovijo spodbudno okolje, kakršno je v HDEE.

\section{USPOSABLJANJE UČITELJEV}

Učitelj v HDEE lahko postane vsakdo, ki ima rad otroke in dobro znanje angleškega jezika. To je pravzaprav osnova, da se kandidat lahko prijavi na usposabljanje (Doron 2010). Tako so kandidati, ki prihajajo na tečaj, pogosto posamezniki, ki imajo izkušnje z otroki, kot npr. varuške ali starši. Druga vrsta kandidatov pa prihaja z izkušnjami v javnem šolstvu oz., kot se Helen malo cinično izrazi, 'proper' education. Za te kandidate pa metodologija HDEE, pravi Doron (prav tam), predstavlja drugačne, včasih celo zastrašujoče izzive. Učitelj se mora namreč po njenem mnenju osvoboditi ideje klasičnega razreda, zato usposabljanje za učitelje vsebuje aktivne delavnice, kjer kandidati igrajo igrice, izvajajo skeče, igrajo igro vlog, se plazijo po tleh ... Vse to, da izgubijo zadržke in se znebijo mišljenja avtoritativnega učitelja. (Doron 2010).

Usposabljanje učiteljev lahko traja 5, 6, ali 7 dni, odvisno od tega, kje se izvaja. Usposabljanje za učitelje poteka v dveh fazah. Prva dva dneva sta uvodna in služita ocenjevanju primernosti kandidatov. Kandidati si lahko pobližje ogledajo materiale in 
metodologijo, medtem ko vodje usposabljanja lahko ocenijo primernost kandidatov. Kandidati za učitelja, ki so ocenjeni kot primerni za HDEE, lahko začnejo z drugim delom usposabljanja, kjer se naučijo metodologije ter spoznajo učne komplete in vodnike za učitelje ter vadijo, kako voditi učne ure. Kandidati, ki zadostijo HDEE-standardom pri praktičnih prikazih učnih ur, pisnih zadolžitvah in splošnem odnosu, dobijo potrdilo o uspešno opravljeni licenci za učitelja HDEE. Vsi kandidati prejmejo komplete za poučevanje, ki vsebujejo učbenike in zvočne zapise, vodnike za učitelje, slikovne kartice in druge učne pripomočke, poleg tega pa še promocijska orodja, kot so datoteke za oglaševanje in medijski paket ter praktične informacije o tem, kako voditi lasten posel (www. helendoron.si).

Usposabljanja za učitelje, ki jih izvajajo v HDEE so zelo podobna usposabljanjem, ki se izvajajo na fakultetah za zgodnje poučevanje tujih jezikov. Tudi tu je pomembna teoretična osnova o razvojnih značilnostih otrok, o didaktiki zgodnjega poučevanja TJ ter o delu z razredom na splošno. Tudi na fakultetah se morajo študenti postaviti v vlogo učencev in praktično preizkušajo dejavnosti, ki jih kasneje izvajajo v razredu. V primerjavi z usposabljanjem za HDEE učitelja, pa imajo učitelji na fakulteti večletno izobraževanje, saj se je didaktike zgodnjega poučevanja težko naučiti v nekaj dneh.

\section{REZULTATI HDEE}

Doron (2010) v svoji knjigi in tudi na mnogih videoposnetkih opisuje 25-letni uspeh HDEE. Pravi, da je vsaka metodologija, ki odstopa od običajne prakse, le zanimiva teorija, dokler se ne vključi v prakso. In tudi s praktičnim izvajanjem traja več let, preden so učinki lahko ovrednoteni. Avtorica metode trdi, da bi bilo zanimivo slediti napredku učencem, vendar do sedaj še niso izvedli takšne raziskave. Kljub temu pravi, da so tu tudi drugi pokazatelji, ki kažejo na uspešnost metode (prav tam: 59):

- otroci se vračajo iz leta v leto,

- $\quad$ starši vpisujejo tudi druge otroke, ko se njihove družine povečajo, in

- HDEE je največji mednarodni center za poučevanje angleščine na svetu.

\section{RAZISKAVA}

Na spletu nisva našli nobene neodvisne empirične raziskave o metodi HDEE, zato sva opravili manjšo empirično raziskavo v ljubljanskem učnem centru Helen Doron Early English. Ker sva želeli sistematično analizirati in predstaviti posamezen primer - poučevanje angleščine po metodi Helen Doron v jezikovnem centru Helen Doron Early English v Ljubljani, sva kot raziskovalno metodo izbrali kvalitativno raziskavo, študijo primera. 
Cilj raziskave je podrobno raziskati metodo za poučevanje angleščine v zgodnjem obdobju, Helen Doron Early English in preveriti, kako delujejo njeni principi v praksi na osnovi ene institucije. To pomeni, da je treba raziskati, kako poteka poučevanje, kakšni so didaktični pristopi, pripomočki, metode, tehnike, kako sodelujejo otroci, kakšna je razredna klima, aktivnost učencev, kako so zadovoljni starši ... Glavni cilj pa je ugotoviti, ali in zakaj je metoda uspešna in če se praksa ujema s teoretičnimi načeli.

Nekaj glavnih raziskovalnih vprašanj sva si zastavljali že pred raziskovanjem. Med raziskovanjem pa so se postavljala tudi nova raziskovalna vprašanja. Ta vprašanja so bila tudi vodilo pri izbiri tehnik raziskovanja. V članku bova tudi analizo predstavili glede na glavna raziskovalna vprašanja.

Uporabili sva štiri tehnike raziskovanja: strukturirano opazovanje z udeležbo (3 opazovanja), intervjuje s starši (4 intervjuje), intervju z učiteljico, intervju z zastopnico HDEE za Slovenijo in direktorico ljubljanskega centra, Nino Žerjal.

\section{INTERPRETACIJE IN SKUPNA ANALIZA KATEGORIJ GLEDE NA POMEMBNEJŠA RAZISKOVALNA VPRAŠANJA}

V članku bova predstavili analizo po kategorijah glede na glavna raziskovalna vprašanja. V posamezni kategoriji sva združili in analizirali podatke, ki sva jih dobili z različnimi raziskovalnimi tehnikami $-\mathrm{z}$ analizo literature, $\mathrm{z}$ opazovanjem ur izvajanja in $\mathrm{z}$ intervjuji s starši, učiteljico ter direktorico centrov.

\subsection{Učenje je zabava}

Eno izmed temeljnih načel HDEE metodologije je, da je učenje zabavno. K temu sicer stremijo tudi druge metode zgodnjega poučevanja jezikov, saj se otrokom prav z igro in na zabaven način najlažje približa tuj jezik. To sva videli tudi med opazovanjem vseh opazovanih ur v HDEE. Učenci so se med aktivnostmi vidno zabavali in tudi aktivno sodelovali. Tudi ko sva o tem povprašali starše, so odgovorili, da se otroci med urami zabavajo in da radi hodijo na tečaj. Tudi vse učiteljice so rekle, da se zelo trudijo, da bi se otroci zabavali in sodelovali ter da se po njihovem mnenju to dogaja vsako uro.

\section{2 Popolna imerzija}

Helen Doron (2010) pravi, da je popolna imerzija edini način, da se otroci tako dobro naučijo angleščine, kot bi bila njihov materni jezik. Tudi direktorica pravi, da se samo tako lahko dobro naučijo angleščine - na način maternega jezika -, torej da tisto uro vse poteka v angleščini. Tudi intervjuvana učiteljica je podobnega mnenja. Pravi, da je pri najmlajših 
to sploh dobro, saj so navodila tako preprosta, da jih zelo lahko razloži samo v angleščini. Malo več je težav pri starejših, kjer je treba razložiti kakšne zakonitosti jezika. Za to se porabi več časa in otroci včasih ne razumejo čisto vsega. Med opazovanimi urami so otroci razumeli večino navodil kljub temu, da so bila samo v angleščini (tudi s pomočjo kretenj, mimike). Mnenja staršev so glede tega različna. Staršu 1 in 2 se to zdi prednost (eden od njiju pravi, da zato, ker popolnoma zaupa metodi). Stařs 3 je glede tega neopredeljen, starš 4 pa ni zadovoljen s popolno imerzijo. Čim večjo rabo TJ pri zgodnjem poučevanju poudarjajo tudi drugi strokovnjaki (npr. Brewster idr. 2002), ki se strinjajo s tem, da se z rabo mimike, slikovnih gradiv in ostalih načinov podajanja snovi da omejiti rabo MJ v razredu.

\subsection{Učni cilji}

Vsi intervjuvanci (starši, učiteljica in direktorica centrov) so povedali, da so staršem cilji na začetku leta predstavljeni ter da se ob koncu vsake enote naredi povzetek, kako otrok napreduje glede na cilje. Pri starejših otrocih se ob koncu vsake enote izvajajo posebna preverjanja. Helen Doron pa v svoji knjigi (2010) odločno nasprotuje preverjanju otrok, zato naju je ta podatek kar malo presenetil. Ko sva o tem vprašali direktorico, nama je pojasnila, da imajo v HDEE čisto posebno preverjanje, ki ni podobno klasičnemu. Glede cilja 660 besed za tečaj FWF (Fun With Flupe za starost $2-6$ let), ki je zapisan na internetni strani, sva dobili zelo različne odgovore. Starši so odgovorili, da za ta cilj niti ne vedo, le eden od njih je rekel, da se nekaj spomni z internetne strani. Ko sva jim povedali, da je ta cilj zapisan na spletni strani, so se strinjali, da je ta cilj za tako majhne otroke pretiran. Pravijo, da morda na tečaju zares slišijo oz. obravnavajo toliko besed, vendar njihov otrok jih toliko gotovo ne pozna. Tudi učiteljica nama je odgovorila, da za ta cilj niti ni vedela. Pojasnila nama je, da besedišče pri tečaju FWF obsega 660 besed, vendar pravi, da je cilj poznati vse te besede za to starost otrok nekoliko pretiran. Pravi, da je verjetno zapisan bolj v promocijske namene. Tak občutek sva dobili tudi sami, zato naju je s svojim odgovorom zelo presenetila direktorica. Takoj ob vprašanju je vedela, kje je ta cilj zapisan, in pravi, da za njim trdno stoji. Z nama se je strinjala, da je številka za to starost visoka, vendar pravi, da je realna. Pojasni, da ne znajo vsi otroci, ki obiskujejo ta tečaj, izgovoriti 660 besed, jih pa gotovo poznajo. Nekateri pa jih znajo tudi izgovoriti. Pravi, da k temu pripomorejo tudi avdioposnetki, ki jih morajo otroci vsak dan poslušati doma. Helen Doron zase pravi, da je velika zagovornica znanstvenosti. Tu lahko izpostaviva, da kljub vsem tem njenim trditvam in oglaševanju ni bilo empirične raziskave, ki bi potrdila ta cilj.

\section{4 Metoda HDEE - v čem se razlikuje od drugih}

Helen Doron tako v svoji knjigi kot tudi na predstavitvenih posnetkih na spletu kar precej kritizira »tradicionalno učenje tujega jezika« Tudi učitelje javnega šolstva je opisala kot stroge učitelje, ki otroke preveč popravljajo in delajo z njimi samo frontalno ter se ne 
znajo spustiti na njihov nivo (glej 3. in 5. poglavje). Vendar Doron v svoji knjigi opisuje tradicionalni model učenja in poučevanja $\mathrm{v}$ javnih šolah, kakršen je bil pred reformami, ki so jih prinesla novejša spoznanja o naravi učenja. Ta se navezujejo na konstruktivistično, izkustveno in inovativno učenje, ki približajo učni proces življenju in pripravljajo učenca na reševanje teoretičnih ter praktičnih vprašanj (Marentič Požarnik, 1998).

Doron (2010) pravi, da je učitelje iz sistema težko »preobraziti« za to metodo. Pravi, da je metodologijo razvila kot odziv na vse te napake. Metodologija HDEE temelji na štirih temeljnih dejavnikih: domače poslušanje posnetkov, pozitivna spodbuda, učenje je zabava, graditi na uspehu. Sicer pa Helen Doron (prav tam) pravi, da se njihova metoda od drugih razlikuje predvsem v svoji edinstvenosti in zelo zgodnjem začetku. Ob opazovanju ur sva opazili vse štiri dejavnike, na katerih naj bi metoda temeljila. Kar se tiče samih tehnik učenja, so uporabljene splošne metode in tehnike za poučevanje angleščine na zgodnji stopnji, ki se uporabljajo tudi v šolah, na drugih tečajih: slikovne kartice, gibalne igre, ples, igra, poučne pesmice ... Pri izvajanju vseh dejavnosti v HDEE je zelo pomembno dejstvo, da so skupine zelo majhne, ureditev prostora pa je primerna izvajanju dejavnosti. Tako se učitelj lahko posveti vsakemu otroku brez posebnega truda in ni izgubljanja časa z ureditvijo prostora za posamezno dejavnost.

Če potegneva vzporednice s šolo, lahko poveva, da Doron v svojih kritikah opisuje zares tradicionalen, zastarel način poučevanja. Tudi intervjuvana učiteljica je rekla, da je med študijem na opazovanju pouka angleščine v nižjih razredih opazila veliko podobnosti s HDEE, vendar pravi, da je v šoli veliko odvisno od učiteljice. Pri HDEE so programi sestavljeni tako, da so preprosti za izvajanje in nihče ne more delati po svoje, torej so cilji zagotovo izpolnjeni. Direktorica je na to vprašanje odgovorila podobno kot Helen Doron. Pravi, da kar je drastično drugačno od drugih načinov poučevanja, je celotna HDEE-metoda ter da tečaj že od začetka vključuje vse prvine jezika in jih nato samo nadgrajuje. Poleg tega so tu pomembni še poslušanje domačih posnetkov in skrbno pripravljeni učni načrti ter materiali, ki so enostavni za izvajanje. Izpostavi tudi delo na tleh in dejstvo, da se v metodi dolgo ne piše, da otrok najprej usvoji druge prvine, kot sta poslušanje in govor, kar je, kot sva že omenili, temeljno načelo tudi v drugih metodah zgodnjega poučevanja TJ.

\subsection{Leksikalno znanje}

Helen Doron (2010) v svoji knjigi daje velik poudarek leksikalnemu znanju in pravi, da je tudi na svojih otrocih videla, kako jezikovni razvoj vpliva na razvoj kognitivnega mišljenja, zato je tudi v metodi HDEE veliko leksikalnega znanja. Pri opazovanju ga sicer ni bilo, vendar sta nama tako učiteljica kot tudi direktorica potrdili, da ga uporabljajo. Učiteljica iz izkušenj pove, da predvsem najmlajši otroci sploh nimajo problemov s tem, da se namesto besede roža ob sliki neke rože to rožo okliče za orhidejo. Pravi, da so starejši otroci na začetku malo zmedeni, vendar se navadijo. Še bolj prepričljivi pa so 
bili odgovori direktorice, ki je poleg teoretične razlage dodala še, da rezultate razvijanja leksikalnega znanja videva dnevno in da zares deluje. Leksikalno znanje je Helen Doron, kot tudi mnogo drugih načel svoje metode, povzela po Glennu Domanu.

\section{6 Starši in domače delo}

O domačem delu sva med raziskavo dobili kar nekaj različnih vidikov. Doron (2010) v svoji knjigi piše, da sta dve vrsti domačega dela in da je vključenost staršev pomemben del metode. Eno je obvezno vsakodnevno poslušanje posnetkov, drugo pa je material, ki omogoči tudi aktivno sodelovanje staršev pri učenju angleščine. Tudi ostali pristopi za poučevanje tujega jezika poudarjajo, da je pomemben čim večji vnos jezika (npr. komunikacijski pristop). Helen Doron to realizira (tudi) s poslušanjem posnetkov. V knjigi Doron piše tudi o dveh vrstah staršev, in sicer starši, ki želijo aktivno sodelovati pri otrokovem izobraževanju, in starših, tipa »hands off« (roke stran), ki izobraževanje prepustijo institucijam. Pomembno je prepričati starše, ki so bolj na način »hands off«, da otrokom zares vsakodnevno predvajajo posnetke. Med raziskavo sva v vseh intervjujih glede domačega delo slišali le o obveznem delu - poslušanju posnetkov. Tako direktorica kot tudi učiteljica sta povedali, da je to poslušanje posnetkov zares ključno in da so vse starše pred tečajem o tem podučili. Obe sta govorili tudi o nekaj primerih, ko starši otrokom niso vsakodnevno predvajali posnetkov in je bil otrok v velikem zaostanku. $\mathrm{V}$ teh primerih so se s temi starši pogovorili. $\mathrm{O}$ takšnih primerih in takšnem ukrepanju je govorila tudi Helen Doron (prav tam). Tudi sami sva med intervjuji staršev opazili, da se starši ne zavedajo, kako pomemben del metode je to. Starši druge vrste domačega dela niso poznali, trije od njih so menili, da je domače delo samo poslušanje posnetkov, starš 4 pa je dejal, da po občutku z otrokom poslušata obvezne posnetke in da po občutku kdaj pogledata tudi ostali material. Prav tako so vsi starši dejali, da pred začetkom obiskovanja tečaja $\mathrm{z}$ otroki niso delali nič za učenje angleščine, le en starš je dejal, da včasih pogledajo kakšno angleško risanko s tem namenom. Torej lahko zaključiva, da so intervjuvani starši bolj na način »hands off « (roke stran), kot je napisala Helen Doron v svoji knjigi. Prav tako pa tudi v intervjujih z učiteljico in direktorico nisva zasledili, da bi jim predlagali še kakšno drugo domače delo. V vseh intervjujih so vprašani povedali, da zaupajo metodi in se jim zdi to dovolj.

\subsection{Najprimernejši začetek učenja tujega jezika}

Odgovori so bili kar pričakovani. Vsi so večinoma odgovarjali v smislu »čim prej, tem bolje«. Starši so to povezali tudi s svojimi slabimi izkušnjami, saj so sami učenje tujega jezika povezovali s težavnostjo, zato želijo, da se njihovi otroci jezik naučijo preko igre. Najprimernejša starost se jim zdi 2-3 leta. Tudi učiteljici se zdi najprimernejša starost za začetek 3 leta. Poudarila je, da je zelo zgodaj dobro za otroka predvsem zato, da se ob učenju zabava ter da še ni obremenjen z učenjem. Direktorica je rekla, da je najprimernejša 
starost za začetek 3 mesece. Kot prednost zgodnjega učenja je izpostavila to, da se otroci ne ustrašijo tuje govorečega človeka. Zanimivo je, da Doronova pomena zgodnjega učenja ni podkrepila s katero od uveljavljenih znanstvenih metod in raziskav. Lightbown in Spada (2013: 204) sta v svojih raziskavah namreč ugotovili, da je načelo »čim prej, tem bolje« odvisno od več dejavnikov. Če je cilj čim bolj približati se znanju domačega govorca, potem je priporočljivo začeti čim prej z učenjem jezika, da je otrok dalj časa izpostavljen jeziku, a izpostavljenost jeziku 1-2 uri na teden ne bo učinkovita. Tako naj bi bil učenec čim večkrat v stiku s tujim jezikom, prav tako pa je pomembna kontinuiteta učenja. Če pa je cilj osnovna komunikacijska sposobnost, potem so starejši začetniki na zgodnji stopnji učinkovitejši kot mlajši otroci, saj jih odlikujejo boljše miselne sposobnosti.

\section{8 Uspeh otrok, zadovoljstvo z metodo}

Vsi intervjuvani starši so skozi intervjuje kazali zadovoljstvo z metodo in popolno zaupanje v metodo. Staršu 1 in staršu 2 se zdi za to starost dovolj že uživanje v aktivnostih v angleščini, staršu 3 se zdi, da se otroci ob tem ogromno naučijo, starš 4 pa je izpostavil, da bo konkretno znanje pokazal čas. Sami sva med opazovanjem videli velik interes otrok za sodelovanje v vseh aktivnostih in tudi kar nekaj uporabe znanja angleščine med temi aktivnostmi. Videlo se je, da aktivnosti že dobro poznajo, vendar so vmes pokazali tudi konkretno znanje (npr. poznavanje besedišča). Tudi učiteljica je zadovoljna z uspehom otrok in tudi ona poudari, da je velik uspeh in zadovoljstvo videti otroke, kako uživajo ob angleških aktivnostih, starejši pa pokažejo tudi kar veliko znanja. Tako direktorica, kot tudi Helen Doron, poudarjata neverjeten uspeh otrok v tej metodi. Pri tem lahko izpostaviva tudi zaupanje v cilj 660 besed na tečaju FWF, ki se marsikomu, tudi staršem in učiteljici, zdi malo previsok za to starostno obdobje. Vendar direktorica trdno stoji tudi za tem ciljem. Ko sva jo povprašali o empiričnem dokazu, pove, da se tega ne da preveriti ter da to tudi ni del metodologije HDEE. Pravi, da so rezultati vidni in da se starši zato vračajo, kar je dovolj dober dokaz.

Mlajši učenci se na splošno radi učijo TJ, kar je pokazala tudi raziskava Juriševičeve (2009), saj je kar 79 \% slovenskim učencem prvega triletja osnovne šole pouk tujega jezika zelo všeč, 19 \% pa je srednje všeč $(\mathrm{N}=591)$ in kar 84 \% učencev se ga rado uči, $14 \%$ pa srednje rado, kar kaže na to, da je učenje tujega jezika mlajšim otrokom všeč tudi v osnovni šoli.

\section{ZAKLJUČEK}

Cilj raziskave je bil podrobneje raziskati metodo HDEE, in sicer najprej metodološko osnovo, nato pa tudi, kako se teorija odraža v praksi ter zakaj je metoda tako uspešna po vsem svetu. Zanimalo naju je tudi, v čem se metoda tako zelo razlikuje od drugih 
načinov poučevanja, kar rada poudari nosilka metode. Že med prebiranjem literature sva namreč ugotovili, da lahko potegnemo veliko vzporednic med »tradicionalnimi« metodami za poučevanje angleškega jezika na zgodnji stopnji (primerjaj Skela in Dagarin Fojkar 2009) ter metodo Helen Doron. Ena večjih prednosti metode je prav gotovo zgodnji začetek. Vendar, za nekatere je kot zgodnji začetek mišljena starost 3-6 let, za Helen Doron pa 3 mesece. Pomembna vzporednica med metodo HDEE in ostalimi načini poučevanja angleščine na zgodnji stopnji obstaja tudi pri metodah dela ter strategijah poučevanja. Ker Helen Doron poudarja posebne strategije poučevanja, sva bili na njih med opazovanjem posebej pozorni. Lahko zaključiva, da uporabljene oblike, tehnike, dejavnosti in naloge $\mathrm{v}$ večji meri sovpadajo s tistimi, ki jih uporabljajo $\mathrm{v}$ ostalih kvalitetnih oblikah zgodnjega poučevanja angleščine (javna šola, drugi tečaji). V naslednjih odstavkih bova povzeli ugotovitve glede uspešnosti metode.

Direktorica pravi, da se odgovor skriva v celotni metodi. Tudi sami sva prišli do podobnega zaključka. Pravzaprav metoda vsebuje vse, kar je najbolj primerno za zgodnje usvajanje tujega jezika. Ker so učenci mlajši ob začetku učenja, temelji pristop na igri in na razvijanju poslušanja in govora, tako kot pri usvajanju maternega jezika. Tehnike, strategije in dejavnosti se pri metodi HDEE ne razlikujejo od drugih načinov poučevanja angleščine na zgodnji stopnji, vendar, kot se je izrazila intervjuvana učiteljica, je pri HDEE vse še bolj »hands on« (konkretno). Ker so skupine zelo majhne, je vse lahko zelo konkretno, vsak učenec ima možnost delati z raznovrstnim didaktičnim materialom, učitelj pa se lahko posveti vsakemu učencu. Majhne skupine omogočajo tudi, da učitelj vsakega otroka spodbuja h govoru. Velik plus so tudi učni načrti, ki so zelo dodelani, torej tudi učitelj brez izkušenj lahko dokaj kvalitetno izpelje uro. Tudi sicer je vse v HDEE zelo standardizirano - tako načini poučevanja kot tudi oprema prostorov, didaktični pripomočki idr. V metodi HDEE se morajo učitelji in franšizorji strogo držati vseh pravil HDEE. Večkrat sva prebrali, da Helen Doron poudarja, da je najpomembnejši izbor master franšizorja. V vseh pogovorih z zastopnico za Slovenijo sva začutili veliko pripadnost metodi in popolno zaupanje vanjo. Helen Doron Educational Group (HDEG), ki skrbi za razvoj metode, materialov, nadgradnjo programov, izvajanje seminarjev, tudi skrbi za veliko medijsko prepoznavnost. Na internetu je veliko posnetkov, kjer Helen Doron predstavlja metodo ali posamezne prvine metode. Za prepoznavnost $\mathrm{v}$ posamezni državi izvajajo predstavitve na raznih otroških sejmih, $v$ trgovskih centrih, reklame lahko opazimo v nekaterih revijah.

Lahko zaključiva, da je metoda vsekakor dobra, saj vsebuje vse prvine kvalitetnega zgodnjega poučevanja tujega jezika, ne razlikuje pa se v večji meri od ostalih pristopov k zgodnjemu poučevanju tujih jezikov. Prav tako bi pričakovali, da bi se v vseh letih izvajanja metode izvedla objektivna longitudinalna empirična raziskava, ki bi potrdila njeno uspešnost. 


\section{LITERATURA}

BREWSTER, J./G. ELLIS, D. GIRARD (2002) (2. izd.) The Primary English Teacher's Guide. London: Penguin Books.

BRUMEN, M. (2000) Razvoj sporazumevalne zmožnosti in učenja tujega jezika na razredni stopnji osnovne šole v programu jezikovne kopeli. I. Štrukelj (ur.), Kultura, identiteta in jezik v procesih evropske integracije. Ljubljana: Društvo za uporabno jezikoslovje Slovenije.

BRUMEN, M. (2003) Pridobivanje tujega jezika v otroštvu. Ljubljana: DZS.

CAMERON, L. (2001) Teaching Languages to Young Learners. Cambridge: Cambridge University Press.

Committee on Children with Disabilities. The treatment of neurologically impaired children using patterning. Pediatrics 104: 1149-1151, 1999. http://web.archive.org/ web/20030130115642/members.carol.net/ ndsc/doman.html/.

ČOK, L. (1999) Načela pouka tujega jezika. L. Čok, J. Skela, B. Kogoj, C. Razdevšek - Pučko (ur.), Učenje in poučevanje tujega jezika. Smernice za učitelje v drugem triletju osnovne šole. Ljubljana in Koper: Pedagoška fakulteta in ZRS RS, 59-60.

DORON, H. (2010) The Music of Language. Israel: Helen Doron Educational Group.

Helen Doron. 5. september 2014. http://www.helendoron.com/.

Helen Doron English Slovenija. 5. september 2014. http://www.helendoron.si/.

JAZBEC, S. (2008) Sporazumevanje v tujih jezikih - Uvajanje tujega jezika in medkulturnega/medjezikovnega uzaveščanja v 1. VIO v OŠ. Maribor: Filozofska fakulteta Maribor. 18. november 2014. http://www.zrss.si/projektiess/skladisce/ sporazumevanje_v_tujih_jezikih/tuj\%20jezik\%20v\%20prvem $\% 20$ triletju/Strokovni $\% 20 \% \mathrm{C} 4 \% 8 \mathrm{Dlanki} \% 20 \mathrm{in} \% 20$ prevodi/projekt_zgodnje_ucenje_sasa_jazbec_28_08.2008.pdf/.

JURIŠEVIČ, M. (2009) Zaznavanje pouka tujega jezika v prvem obdobju osnovne šole in motiviranost učencev za učenje. K. Pižorn (ur.), Učenje in poučevanje dodatnih jezikov v otroštvu. Ljubljana: Zavod Republike Slovenije za šolstvo, 97-115.

KLADNIK, M. (2014) Poučevanje angleščine na zgodnji stopnji po metodi Helen Doron. Ljubljana: Pedagoška fakulteta (diplomsko delo).

KRASHEN, D. S./T. D. TERRELL (1983) The Natural Approach. Language Acquisition in the Classroom. Hayward, California: Alemany Press.

LENNEBERG, E. H. (1967) Biological Foundations of Language. New York: Academic Press.

LIGHTBOWN, P. M./N. SPADA (2013) (4. izd.) How Languages are Learned. Oxford: Oxford University Press. 
MARENTIČ POŽARNIK, B. (1998) Kako pomembna so pojmovanja znanja, učenja in poučevanja za uspeh kurikularne prenove. Sodobna pedagogika, 49/3, 244-261.

MURPHY, V. A. (2014) Second Language Learning in the Early School Years: Trends and Contexts. Oxford: Oxford University Press.

PENFIELD, W./L. ROBERTS (1959) Speech and brain mechanisms. Princeton NJ: Princeton University Press.

PEVEC SEMEC, K. (ur.), (2013) Učni načrt. Program Osnovna šola. Tuji jezikv 2. in 3. razredu. Ljubljana: Ministrstvo za izobraževanje, znanost in šport, Zavod Republike Slovenije za šolstvo.

PINTER, A. (2006) Teaching Young Language Learners. Oxford: Oxford University Press. PIŽORN, K. (2009) Učenje in poučevanje dodatnih jezikov v otroštvu. K. Pižorn (ur.), Učenje in poučevanje dodatnih jezikov $v$ otroštvu. Ljubljana: Zavod Republike Slovenije za šolstvo, 12-25.

Prof. H. Boettger study of Helen Doron English students in Germany. 10. september 2014. https://www.youtube.com/watch?v=zNJfB_8E-Os/

SKELA, J./M. DAGARIN FOJKAR (2009) Presek teorij učenja in poučevanja drugega/ tujega jezika v otroštvu. K. Pižorn (ur.), Učenje in poučevanje dodatnih jezikov v otroštvu. Ljubljana: Zavod Republike Slovenije za šolstvo, 26-63.

STERN, H. H. (1983) Fundamental Concepts of Language Teaching. Oxford: Oxford University Press.

SUZUKI, S. (1981) Ability development from age 0. Secaucus N.J.: Suzuki Method International.

Suzuki method. 15. september 2014. http://www.suzukimusic.org.au/suzuki.htm\#history/. The Institutes for the Achievement of Human Potential. 10. september 2014. http://www. iahp.org/.

\section{ABSTRACT}

\section{Teaching Early English by Following the Method of Helen Doron}

Plurilingualism is taking a leading role on the threshold of the $21^{\text {st }}$ century; at the level of the world, Europe, the European Union and Slovenia as well as at the level of each individual. As a result, more and more language institutions are being established all over the world. The article focuses on the Helen Doron Early English method with its own worldwide centres for learning English. The most important influences on the development of the methodology are described in detail; the Glenn Doman method and, the most influential one, the Suzuki method. The article furthermore encompasses Helen Doron's criticism of the traditional school system, teacher training and the results of the Helen Doron Early English. A qualitative research (a case study) is described in the empirical part, which was administered in the Ljubljana Helen Doron Early English Centre. The results of the analysis are presented through research questions. The 
conclusion comprises the main features of the method and a proposition for upgrading the research with an objective longitudinal empirical research.

Keywords: early foreign language learning, methods and strategies for learning English, Helen Doron Early English method, Glenn Doman method, Suzuki method.

\section{POVZETEK}

\section{Poučevanje angleščine na zgodnji stopnji po metodi Helen Doron}

Pojem večjezičnost ima na pragu 21. stoletja vse večjo vlogo na vseh ravneh; na ravni sveta, Evrope, Evropske unije, Slovenije, posameznika. Posledično nastaja tudi vedno več jezikovnih institucij po vsem svetu. V članku je podrobneje predstavljena metoda za učenje angleščine Helen Doron Early English z lastnimi jezikovnimi centri za učenje angleščine po celem svetu. Opisana sta najpomembnejša vpliva na razvoj metodologije; metoda Glenna Domana in Suzukijeva metoda. Članek zajema tudi Doronino kritiko tradicionalnega šolskega sistema, usposabljanje učiteljev ter rezultate Helen Doron Early English. V raziskovalnem delu je opisana kvalitativna raziskava (študija primera), ki je bila opravljena v ljubljanskem centru Helen Doron Early English. Rezultati analize so predstavljeni po posameznih raziskovalnih vprašanjih. V zaključku so povzete glavne lastnosti metode in predlog za nadgraditev raziskave $\mathrm{z}$ objektivno longitudinalno empirično raziskavo o rezultatih metode.

Ključne besede: zgodnje poučevanje tujega jezika, metode in strategije za poučevanje angleščine, metoda Helen Doron Early English, metoda Glenna Domana, Suzukijeva metoda 